\title{
The Role of Id2 Protein in Neuroblatoma in Children
}

\author{
Aleksandra Wieczorek • Walentyna Balwierz
}

Received: 5 June 2014 / Accepted: 16 February 2015 / Published online: 14 March 2015

(C) The Author(s) 2015. This article is published with open access at Springerlink.com

\begin{abstract}
Id (DNA binding and/or differentiation) proteins occur physiologically during ontogenesis and negatively regulate the activity of other helix-loop-helix (HLH) proteins. Id2 protein causes block of cells differentiation in the $\mathrm{S}$ phase of the cell cycle and regulates the activity of $\mathrm{Rb}$ protein. The role of Id2 protein in physiological cell cycle progression and in neuroblastoma (NBL) pathogenesis was proposed by Lasorella. The aim of the study was evaluation of Id2 expression and its prognostic significance in NBL cells coming from primary tumors and evaluation of its prognostic significance, and correlation of Id 2 expression with known prognostic factors. Sixty patients with primary NBL treated from 1991 to 2005 were included in the analysis. We found 50 patients with high and 10 patients with low intensity of Id 2 expression. The median percentage of NBL cells with Id2 expression was $88 \%$. We found no correlation between the number of NBL cells or the intensity of Id2 expression and OS and DFS. In patients with stage $4 \mathrm{NBL}$, almost all patients had high expression of Id 2 and it was significantly more common than in other disease stages $(p=0,03)$. We found no correlation between Id 2 expression and other known prognostic factor in NBL patients. We assume that Id2 is not prognostic factor. However, due to its abundant expression in most of NBL cells and its role in cell cycle, it may be potential therapeutic target. Exact knowledge of expression time may be helpful in explaining mechanisms of oncogenesis.
\end{abstract}

Keywords Neuroblastoma $\cdot \operatorname{Id} 2$ protein $\cdot$ Prognostic factor

A. Wieczorek $(\square) \cdot$ W. Balwierz

Department of Pediatric Oncology and Hematology,

Polish-American Institute of Pediatrics, Jagiellonian University

Medical College, Krakow, Poland

e-mail: a.wieczorek@uj.edu.pl

\section{Introduction}

Id (DNA binding and/or differentiation binding) proteins have a helix-loop-helix (HLH) structure (Table 1). They occur physiologically during ontogenesis and negatively regulate the activity of other HLH proteins. Unlike other proteins from the HLH family, Id proteins (Id1 - Id4) lack the DNA binding basic domain. It results in the block of the formation of functional dimers of transcription regulators with tissue-specific differentiation regulators, so the cells differentiation is blocked and the cells come into the phase $\mathrm{S}$ of the cell cycle [1-6]. As the only protein from the HLH family, Id2 can also physically interact with $\mathrm{Rb}$ protein and prevent its antiproliferative activity. As an effect, Id 2 can simultaneously control cell differentiation and cell cycle progression $[1-3,5,7,8]$. It is assumed that, in the condition of abundant Id 2 expression, the increased amount of unphosphorylated $\mathrm{pRb}$ protein is not sufficient for inhibition of cell cycle [2, 3, 7, 8]. During early stages of cell differentiation all proteins from Id family are expressed in many tissues and organs. The time and the level of expression depend on tissues/organs and the stage of differentiation [5, 9-11]. In the postnatal period Id2 expression is described in some postmitotic neurons of the central nervous system $[9,12,14]$. Id 2 expression, as well as MYCN expression, is not physiologically found in normal adrenal glands during postnatal period [15]. Id proteins are necessary for maintaining the immaturity of progenitor cells and their proliferation as long as the established point in their development is reached $[14,16,17]$. This is especially important in control of nervous system cells differentiation and coordination of differentiation with definitive termination of cell proliferation and irreversible block of cell cycle progression $[3,8,9,12,14$, 18-20]. There is also a hypothesis concerning the influence of Id 2 proteins on primary neoplastic cells (tumor stem cells). In such a case the presence of Id2 protein even in the single neoplastic cell could confirm its crucial role in tumor 
Table 1 Abbreviations list

\begin{tabular}{ll}
\hline DFS & disease free survival \\
\hline HLH & helix-loop-helix \\
Id & DNA binding and/or differentiation protein \\
NBL & neuroblastoma \\
OS & overall survival \\
RT-PCR & reverse transcription polymerase chain reaction \\
\hline
\end{tabular}

development [21, 22]. The high level of Id2 protein was found in some NBL cell lines with MYCN amplification. Features characteristic for cells with high activity of Myc family protein, as ability to enter the cell cycle without the presence of growth factors and ability of cooperation with ras protein are supposed to be dependent on Id2 protein function [14, 23]. Lasorella et al. found that excessive Id 2 expression in neuroblastoma (NBL) cells is responsible for neoplastic transformation of precursor cells and its constant expression is required for keeping malignant character of NBL cells $[8,15]$. As Id2 expression is especially crucial for normal nervous cells development the neoplastic cells coming from nervous system might be more sensitive for abnormal Id2 expression [12, 13, $15,18]$

\section{Material and Methods}

The aim of the study was evaluation of Id 2 expression in neuroblastoma cells coming from primary tumors stored as paraffin blocks taken from patients at diagnosis, evaluation of its prognostic significance and correlation between Id2 expression and known prognostic factors. Sixty patients were included in the analysis, treated for NBL in the Department of Oncology and Hematology in Krakow from 1991-2005. Observation was finished in June 2012. The characteristics of patients are presented in Table 2. Analysis of the significance of Id 2 protein expression was performed both for the whole group of patients and for subgroups defined according to chosen established prognostic factors, as age, clinical stage of disease and MYCN amplification (Table 3).

Id 2 expression was evaluated with immunohistochemistry. Staining was performed with rabbit anti-Id 2 antibodies (Zymed Laboratories Inc.) on silanized slides. According to manufacturer guidelines, the optimal dilution of primary antibody was experimentally established as 1:100 and the time of incubation as $45 \mathrm{~min}$. The detection system was based on peroxidase (EnVision + System-HRP ${ }^{\circledR}$, DacoCytomation) for use with rabbit primary antibodies, for evaluation in light microscopy of paraffin embedded tissue. As the positive control NBL cell line SKNSH was used with known high Id2 expression. As the second control human testis was used, embedded in paraffin. The double control system was chosen because we wanted to compare staining procedures in the samples prepared under the same conditions in our laboratory (testis tissue, unlike the cell line, underwent the same deparaffinization procedures and antigen unblocking). In negative control, no primary antibody was added. The percentage of cells with Id2 expression was evaluated in the light microscopy. The intensity of Id 2 staining was evaluated by comparison with staining intensity of the positive control.

Estimations of the survival were performed using a Kaplan-Meier method and compared with a log-rank test. The comparisons between groups were performed by a chisquare test (with Fisher's exact test if necessary), Student's $t$ test and Pearson correlation test. For all analyses the $\mathrm{p}$ values less than $0.05(p<0.05)$ were considered as statistically significant. Statistica ${ }^{\circledR}$ software packages were used for statistical analysis.

The influence of intensity of Id2 expression and the percentage of NBL cells with Id 2 expression on mortality and therapy failures (initial progression or relapse) was evaluated.

\section{Results}

Among 60 NBL patients evaluated, we found 50 patients with high and 10 children with low intensity of Id 2 expression. The percentage of NBL cells with the Id 2 expression was 1$100 \%$ (median $88 \%$, mean $77.5 \%$ ). In 53 patients ( $88 \%$ ) the Id 2 expression was found in more then $50 \%$ of cells and in $28(46.7 \%)$ - in over $90 \%$ (Fig. 1$)$.

As the main aim of the study was the evaluation of Id 2 as a prognostic factor, we decided to exclude from the overall survival analysis the patients whose death was not caused by

Table 2 Patient characteristic

\begin{tabular}{|c|c|c|}
\hline Parameters & & $\begin{array}{l}\text { Number of } \\
\text { patients }(\%)\end{array}$ \\
\hline \multirow[t]{2}{*}{ Sex } & Boys & $34(57.0)$ \\
\hline & Girls & $26(43.0)$ \\
\hline \multirow[t]{4}{*}{ Age (months) } & Range & $0,3-169$ \\
\hline & Median & 24,5 \\
\hline & $\begin{array}{l}\text { Number of patients }>12 \\
\text { months of age }\end{array}$ & $41(68.3)$ \\
\hline & $\begin{array}{c}\text { Number of patients }<12 \\
\text { months of age }\end{array}$ & $19(31.7)$ \\
\hline \multirow[t]{5}{*}{ Stage } & 1 & $0(0.0)$ \\
\hline & 2 & $6(10.0)$ \\
\hline & 3 & $17(28.3)$ \\
\hline & 4 & $31(51.7)$ \\
\hline & $4 \mathrm{~s}$ & $6(10.0)$ \\
\hline \multirow[t]{3}{*}{ MYCN amplification } & Present & $12(20.0)$ \\
\hline & Absent & $46(76.7)$ \\
\hline & No result & $2(3.3)$ \\
\hline
\end{tabular}


Table 3 Treatment results depending on intensity of Id 2 staining and number of Id 2 positive cells in the whole group of patients and defined subgroups

\begin{tabular}{|c|c|c|}
\hline & $\begin{array}{l}\text { Intensity of Id } 2 \\
\text { staining } \\
p \text { value }\end{array}$ & $\begin{array}{l}\text { Number of Id } 2 \\
\text { positive cells }\end{array}$ \\
\hline Age at diagnosis & 0.39 & 0.53 \\
\hline $\begin{array}{l}\text { Presence of MYCN } \\
\text { amplification }\end{array}$ & 0.33 & 0.73 \\
\hline \multicolumn{3}{|c|}{ Whole group of patients } \\
\hline Deaths & 0.19 & \\
\hline OS & 0.3 & \\
\hline Therapy failures & 1.0 & \\
\hline DFS & 0.15 & \\
\hline \multicolumn{3}{|c|}{ Patients over 1 year of age } \\
\hline Deaths & 0.35 & 0.79 \\
\hline OS & 0.55 & \\
\hline Therapy failures & 0.58 & 0.07 \\
\hline DFS & 0.53 & \\
\hline \multicolumn{3}{|c|}{ Patients under 1 year of age } \\
\hline Deaths & 0.57 & 0.06 \\
\hline OS & 0.42 & \\
\hline Therapy failures & 0.21 & 0.86 \\
\hline DFS & 0.19 & \\
\hline \multicolumn{3}{|c|}{ Amplification of MYCN } \\
\hline Deaths & & 0.75 \\
\hline Therapy failures & & 0.51 \\
\hline \multicolumn{3}{|c|}{ No amplification of MYCN } \\
\hline Deaths & 0.17 & 0.38 \\
\hline OS & 0.2 & \\
\hline Therapy failures & 0.15 & $0.02 *$ \\
\hline DFS MYCN & 0.13 & \\
\hline
\end{tabular}

*higher number of cells in children without therapy failures

NBL. Deaths occurred in 29 out of 50 patients (23 died of NBL) and 3 out of 10 patients (all caused by NBL) with high and low Id 2 expression, respectively (chi-square, Fisher's exact test, $p=0.19)$. Three-year OS was similar for both groups ( 0.68 and 0.7 in the groups with low and high Id 2 expression, respectively). Five-year OS was higher in patients with low Id2 expression, but the results were not statistically significant $(p=0.3)$. Therapy failure defined as early progression or relapse occurred in 30 out of 50 children with high Id2 expression and 4 out of 10 children with low Id 2 expression (chisquare, Fisher's exact test, $p=1.0)$. No statistically significant differences were found $(p=0.15)$ for 3-year DFS $(0.7$ and 0.48 ) and 5-year DFS (0.7 and 0.4). In 41 evaluated patients over 1 year of age, the percentage of NBL cells with Id2 expression was 1-100 \% (mean: $73.3 \%$, median: $85 \%$ ). In 17 patients $(41.5 \%)$ the percentage of Id2 positive cells was over $90 \%$. In children younger than 1 year of age $(n=19)$ the percentage of cells with Id2 expression was $50 \%-100 \%$ (mean $86 \%$, median $90 \%$ ). In 9 patients (47.4\%) Id 2 expression was found in over $90 \%$ of cells. In patients with stage 4 NBL, only 2 among 31 patients had low expression of Id 2 we did not perform comparative analysis. The percentage of Id 2 positive cells was $1-100 \%$ (mean $74 \%$, median $85 \%$ ). In patients with stage 4 , in comparison to other stages, we found significantly more common high expression of $\operatorname{Id} 2(p=0.03)$ (Fig. 2). The number of cells with high Id2 expression was not higher in patients in stage $4(p=0.46)$. The percentage of Id 2 positive cells in patients in stage 2,3 or $4 \mathrm{~s}$ was $1-100 \%$ (mean $81.7 \%$, median $90 \%$ ). In this group of patients neither intensity of Id 2 expression nor percentage of Id 2 positive cells had influence on treatment outcomes (overall survival or disease relapse and progression). Among 12 patients with MYCN amplification, only 1 had low Id 2 expression. The comparative analysis was not performed. The percentage of Id2 positive cells in patients with MYCN amplification was 40-100 \% (mean $81.2 \%$, median $97.5 \%$ ). Percentage of Id2 positive cells had influence on neither NBL deaths $(p=0.75)$ nor therapy failure $(p=0.51)$ in this group of patients. In patients without MYCN amplification $(n=46)$ the percentage of Id 2 positive cells was $1-100 \%$ (mean $81.2 \%$, median
Fig. 1 Percentage of cells with detectable Id 2 protein expression in the whole group of patients

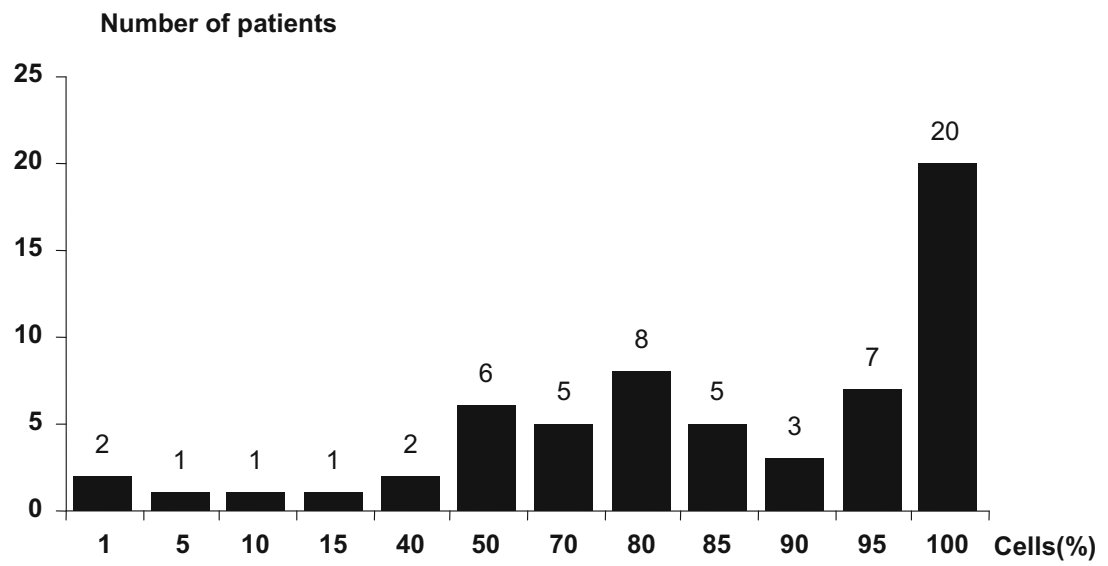




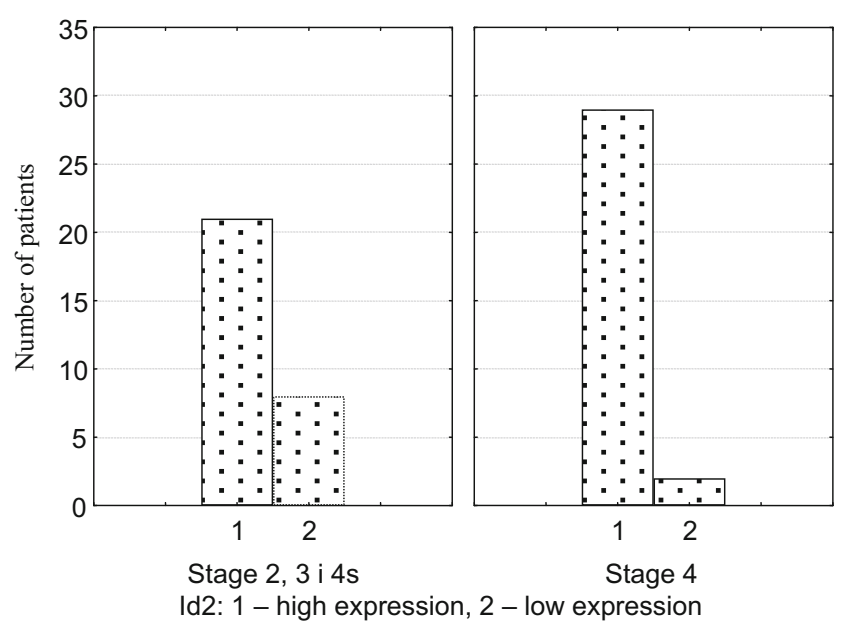

Fig. 2 Number of patients with high and low Id 2 protein expression in children with stage 4 and other stages (2, 3 and 4 s) of neuroblastoma

$97.5 \%)$. The intensity of Id 2 expression was not different in patients with and without MYCN amplification $(p=0.33)$. In the group with no amplification, 15/37 children with high Id2 expression and 2/9 children with low Id 2 expression died of NBL $(p=0.17)$. Therapy failures occurred in $22 / 37$ and $3 / 9$ children, respectively $(p=0.15)$. In patients with no MYCN amplification, 3-year and 5-year OS and DFS were higher in the group with low Id 2 expression. However, the difference was not statistically significant ( $p=0.2$ for OS and $p=0.13$ for DFS). Percentage of Id 2 positive cells had no influence on survival $(p=0.39)$ and on therapy failures $(p=0.2)$.

Number of cells with Id2 expression and intensity of Id2 expression in cells had no statistically significant influence on mortality or therapy failures in the other groups of patients distinguished on the basis of age, stage or status of MYCN amplification. For the whole group and defined subgroups we did not find any correlation between the percentage of cells with Id2 expression and OS, DFS, levels of lactate dehydrogenase (LDH), ferritin or neurospecific enolase (NSE).

\section{Discussion}

Extraordinary biological characteristics of NBL and diverse clinical outcome are the reasons why neuroblastoma is the focus of scientific interest [24-31]. One of the possible mechanisms responsible for oncogenesis is the dysfunction of proteins responsible for growth and differentiation of cells, as Id family proteins. They maintain stem cells pool of the nervous cells and their cytoplasmic sequestration promotes neural differentiation [32]. However, the results of studies concerning the possible meaning of Id2 in NBL remains unclear. In the study of Lasorella [15] they found correlation between expression of MYCN and Id2 protein with statistically significant influence of expression of Id 2 in at least $25 \%$ of cells on OS and DFS $[3,15]$. Other studies did not confirmed these results.
Vandesompele et al. [33] evaluated ID2, MYCN and MYC genes expression in NBL cell lines and did not confirm correlation between mRNA ID2 and either MYCN or MYC. There was no correlation between Id 2 and patients' prognosis. However, there was a trend for better prognosis in patients with Id2 level lower then the mean for the whole group. Alaminos et al. [34] evaluated Id2 in the group of 99 patients and 12 cell lines and did not reveal any correlation between MYCN and Id2 and it had no influence on prognosis. Both proteins and genes were evaluated by Wang et al. [35] in 170 patients and 10 cell lines and they were found in all evaluated tumors and cell lines. Id2 did not correlate with clinical patients' characteristic and it was expressed independently of MYCN status; these results are consistent with the ones obtained in our study. However, we found that almost all patients with MYCN amplification had high Id2 expression, as had the patients in stage 4 NBL. The differences concerning correlation of Id2 with MYCN can be the result of different attitude to MYCN interpretation (amplification vs prognosis) and methods of Id2 evaluation (protein vs gene expression) [36, 37]. Differences in cell culture conditions can be also partially responsible for the observed inconsistent results [33]. It has been proved that Id 2 expression in cell lines is induced by hypoxia, what can partially explain the described dedifferentiation of hypooxygenated NBL cells [38]. It should be also pointed that during normal embryogenesis the appropriate level of Id 2 is crucial in the given time points, so probably for correct interpretation of the significance of Id2 protein expression it would be necessary to know the exact time point of its expression [39].

In our study we found expression of Id 2 protein in all evaluated tumors, with $83.3 \%$ of patients with high expression in most of the cells. As neither the exact level nor the meaning of time of Id 2 expression is confirmed to be informative, we assumed that each observed expression of Id2 will be defined as positive. There are some studies indicating the existence of neoplastic stem cells, in which the mechanisms connected with Id 2 expression can play a potential role in creating and maintaining malignant phenotype of the cell. In our material the intensity of Id 2 expression was comparable in all analyzed groups; however, and lack of statistical significance may be the result of a small number of patients. After analysis of the whole group and subgroups it cannot be confirmed that Id 2 expression has prognostic significance in NBL. In most of univariate analyses, neither level of expression nor number of cells with Id2 expression had statistically significant influence on OS and DFS. However, almost all children with MYCN amplification had high intensity of Id2 expression and more children with strong Id2 expression were in stage 4 of disease.

It has been proved that inhibition of Id 2 function is possible in vitro, and it results in reduction of tumorigenic properties in neuroblastoma cells and promotion of cells differentiation 
[40-42]. Additionally, it has been proved that retinoic acid treatment is associated with negative regulation of ID2 mRNA [43]. Because of common expression of Id 2 in neuroblastic tumors and its known role in nervous system development, it may be a potential therapeutic target and it is necessary to continue work explaining meaning of the level and time of its expression in NBL cells.

Acknowledgments The project was supported by the Ministry of Science and Higher Education research grant N406074 31/2881.

Open Access This article is distributed under the terms of the Creative Commons Attribution License which permits any use, distribution, and reproduction in any medium, provided the original author(s) and the source are credited.

\section{References}

1. Benezra R, Davis RL, Lockshon D, Turner DL, Weintraub H (1990) The protein Id: a negative regulator of helix-hoop-helix DNA binding proteins. Cell 61(1):49-59

2. Iavarone A, Garg A, Lasorella A, Hsu J, Israel M (1994) The helixloop-helix protein Id 2 enhances cell proliferation and binds to retinoblastoma protein. Genes Dev 8:270-284

3. Lasorella A, Noseda M, Beyna M, Yokota Y, Iavarone A (2000) Id2 is a retinoblastoma protein target and mediates signaling by Myc oncoproteins. Nature 407:592-598

4. Liu Y, Encinas M, Comella JX, Aldea M, Gallego C (2004) Basic helix-loop-helix proteins bind to $\operatorname{Tr} k B$ and $p 21^{c i p}$ promoters linking dedifferentiation of hypoxic neuroblastoma cells. J Bioch Chem 24(7):2662-2672

5. Norton JD, Deed RW, Crags G, Sablitzky F (1998) Id helix-loophelix proteins in cell growth and differentiation. Trends Cell Biol 8: $58-65$

6. Yokota Y (2001) Id and development. Oncogene 20:8290-8298

7. Iavarone A, Lasorella A (2004) Id 2 proteins in neural cancer. Cancer Lett 204:270-284

8. Lasorella A, Iavarone A, Israel MA (1996) Id2 specificity alters regulation of the cell cycle by tumor suppressor proteins. Mol Cell Biol 16(6):2570-2578

9. Riechmann V, Sablitzky F (1995) Mutually exclusive expression of two dominant-negative helix-loop-helix (dnHLH) genes, Id4 and Id3, in the developing brain of the mouse suggests distinct regulatory roles of these dnHLH proteins during cellular proliferation and differentiation of the nervous system. Cell Growth Differ 6(7):837-843

10. Zhu W, Dahmen J, Bulfone A, Rigolet M, Hernandez MC, Kuo WL, Rubenstein JRL, Israel MA (1995) Id gene expression during development and molecular cloning of the human Id-1 gene. Mol Brain Res 30(2):312-326

11. Biggs J, Murphy EV, Israel MA (1992) A human Id-like helix-loophelix protein expressed during early development. Proc Natl Acad Scie USA 89:1512-1516

12. Toma JG, El-Bizri H, Barnabe-Heider F, Aloyz R, Miler FD (2000) Evidence that helix-loop-helix proteins collaborate with retinoblastoma tumor suppressor protein to regulate cortical neurogenesis. J Neurosc 20(20):7648-7656

13. Lasorella A, Iavarone A (2006) The protein ENH is a cytoplasmic sequestration factor for Id 2 in normal and tumor cells from the nervous system. Proc Natl Acad Sci U S A 103(13):4976-4981

14. Lasorella A, Uo T, Iavarone A (2001) Id proteins at the cross-road of development and cancer. Oncogene 20:8326-8333
15. Lasorella A, Boldrini R, Dominici C, Donfrancesco A, Yokota Y, Inserra A, Iavarone A (2002) Id2 is critical for cellular proliferation and is the oncogenic effector of N-Myc in human neuroblastoma. Cancer Res 63:301-306

16. Tzeng SF (2003) Inhibitors of DNA binding in neural proliferation and differentiation. Neurochem Res 28(10):45-52

17. Yokota Y, Mori S, Narumi O, Kitajima K (2001) In vivo function of a differentiation inhibitor Id2. Life 51:207-214

18. Gleichmann M, Buchheim G, El-Bizri H, Yokota Y, Klockgether T, Kuegler S, Bahr M, Weller M, Schulz JB (2002) Identification of inhibitor-of-differentiation 2 (Id2) as a modular of neuronal apoptosis. J Neurochem 80:755-762

19. Lee EY, Hu N, Yuan SS, Cox LA, Bradley A, Lee WH, Herrup K (1994) Dual roles of the retinoblastoma protein in cell cycle regulation and neuron differentiation. Genes Dev 8:2008-2021

20. Chen XS, Zhang YH, Cai QY, Zyao ZX (2012) ID2: a negative transcription factor regulating oligodnedroglia differentiation. $\mathrm{J}$ Neurosc Res 90:925-932

21. Al-Haji M, Clarke MFL (2004) Self-renewal and solid tumor stem cells. Oncogene 24:7273-7282

22. Freidenraich D, Stilwell D, Romero E, Wilkes D, Manova K, Basson C, Benezra R (2004) Rescue of cardiac defects in ID knockout embryos by injection of embryonic stem cells. Science 306:247-252

23. Lasorella A, Rothschild G, Yokota Y, Russel RG, Iavarone A (2005) Id2 mediates tumor initiation, proliferation and angiogenesis in $\mathrm{Rb}$ mutant mice. Mol Cell Biol 25(9):3563-3574

24. Balwierz W (2004) Strategie postępowania w nerwiaku zarodkowym współczulnym. Przegl Lek 61(2):3-8

25. Berthold F, Kassenbohmer R, Zieschang J (1994) Multivariate evaluation of prognostic factors in localized neuroblastoma. Am J Pediatr Hematol Oncol 16:107-115

26. Brodeur GM, Maris JM, Jamashiro DM (1997) Biology and genetics of human neuroblastomas. J Pediatr Hematol Oncol 19:93-101

27. Brodeur GM, Seeger RC, Schwabb M, Varmus HE, Bishop JM (1984) Amplifiaction of Myc-N in untreated human neuroblastoma correlates with advanced disease stage. Science 224:1121-1124

28. Caron H (1995) Allelic loss of chromosome 1 and additional chromosome 17 material are both unfavorable prognostic markers in neuroblastoma. Med Ped Oncol 24(4):215-221

29. Cohn SL, London WB, Huang D, Katzenstien HM, Salwen HR, Reinhart T, Madafiglio J, Marshall GM, Norris MD, Haber M (2000) MYCN expression is not prognostic of adverse outcome in advance-stage neuroblastoma with nonamplified MYCN. J Clin Oncol 18(21):3604-3613

30. Oude Luttikhuis MEM, Powell JA, Rees SA, Genus T, Chughtai S, Ramani P, Mann JR, McCoville CM (2001) Neuroblastoma with 11q loss and single MYCN copy comprise a biologically distinct group of tumours with adverse prognosis. Brit J Cancer 85(4):531-537

31. Vandesompele J, Speleman F, Van Roy N, Laureys G, Brinkschmidt C, Christiansen H, Lampert F, Lastowska M, Bown N, Pearson A, Nicolsson JC, Ross F, Combarett V, Delattre O, Feuerstein DG, Plantaz D (2001) Multicentre analysis of patterns of DNA gains and loses in 204 neuroblastoma tumors: how many genetic subgroups are there? Med Ped Oncol 36:5-10

32. Iavarone A, Lasorella A (2006) ID proteins as targets in cancer and tools in neurobiology. Trend Mol Med 12:588-594

33. Vandesompele J, Edsjo D, De Preter K, Axelson H, Speleman F, Pahlman S (2003) ID2 expression in neuroblastoma does not correlate to MYCN levels. Oncogene 22:456-460

34. Alaminos M, Gerald WL, Cheung NKV (2005) Prognostic value of MYCN and ID2 overexpression in neuroblastoma. Pediatr Blood Cancer 45:909-915

35. Wang Q, Guo C, Hii G, Shusterman S, Mosse Y, Zhao H, Cnaan A, Rappaport E, Hogarty MD, Marris JM (2003) ID2 expression is not associated with MYCN amplification or expression in human neuroblastoma. Cancer Res 63:1631-1635 
36. Gebauer S, Yu AI, Omura-Minamisawa M, Batova A, Dicciani M (2004) Expression profiles and clinical relationship of ID2, CDKN1B and CDKN2B in primary neuroblastoma. Genes Chromosomes Cancer 41:297-308

37. Raetz EA, Kim MK, Moos P, Carslon M, Bruggers C, Hooper DK, Foot L, Liu T, Seeger R, Carroll WL (2003) Identification of genes that are regulated transcriptionally by Myc in childhood tumors. Cancer 98(4):841-853

38. Lofstedt T, Jogi A, Sigvardsson A, Gradin K, Poellinger L, Pahlman S, Axelson H (2004) Indcution of ID2 expression by hypoxiainducible factor-1. A role in dedifferentiation of hypoxic neuroblastoma cells. J Biol Chem 279(38):39223-39231

39. Perk J, Iavarone A, Benezra R (2005) Id family of helix-loop-helix protein in cancer. Nat Rev Cancer 5(8):603-614

40. Ciarapica R, Annibali L, Raimondi L, Savino M, Nasi S, Rota R (2009) Targeting Id protein interactions by an engineered HLH domains induces human neuroblastoma cell differentiation 13I and neuroblastoma differentiation. Oncogene 28:1881-1891

41. Han W, Wu Z, Zhao Y, Meng Y, Si Y, Yang J, Fu X, Yu L (2009) FHL2 interacts with and acts as a functional repressor of Id2 in human neuroblastoma cells. Nucleic Acid Research 12(37):3996-4009

42. Hu JG, Wu XJ, Feng YF, Xi GM, Deng LX, Wang ZH, Wang R, Shen L, Zhou JS, Lu HZ (2013) The molecular events involved in oligodendrocyte precursor cell proliferation induced by the conditioned medium from B104 neuroblastoma cells. Neurochem Res 38:601-609

43. Annibali D, Gioia U, Savino M, Laneve P, Caffarelli E, Nasi $S$ (2012) A new module in neural differentiation control: two microRNAs upregulated by retinoic acid, miR-9 and -103 , target the differentiation inhibitor ID2. doi:10.1371/journal. pone.0040269 